\title{
PROMETHEUS
}

Archetypal Image of Human Existence

BOLLINGEN SERIES LXV - I

$\frac{\theta}{6}$ 



\section{Carl Kerényi}

\section{PROMETHEUS}

\section{Archetypal Image of Human Existence}

TRANSLATED FROM THE GERMAN BY

Ralph Manheim

BOLLINGEN SERIES LXV • I

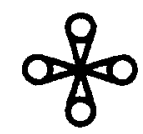

PRINCETON UNIVERSITY PRESS

PRINCETON, NEW JERSEY 
Published by Princeton University Press, 41 William Street, Princeton, New Jersey 08540

In the United Kingdom: Princeton University Press, Chichester, West Sussex

Copyright $@ 1963$ by Bollingen Foundation; copyright renewed $@ 1991$ by Princeton University Press

All Rights Reserved

THIS IS VOLUME ONE IN A GROUP OF STUDIES OF Archetypal lmages of Greek Religion WHICH CONSTITUTE THE SIXTY-FIFTH PUBLICATION IN A SERIES SPONSORED AND PUBLISHED BY BOLLINGEN FOUNDATION

Translated from Prometheus: Die menschliche Existenz in griechischer Deutung, published by Rowohlt Verlag, Hamburg, copyright $\odot 1959$ Rhein-Verlag AG, Zurich. Earlier version: Prometheus: Das griechische Mythologem von der menschlichen Existenz, copyright $\odot 1946$ Rhein-Verlag AG, Zurich

Library of Congress Catalogue Card Number: 59-13516

ISBN-13: 978-0-691-01907-9 (pbk.)

ISBN-10: 0-691-01907-X (pbk.)

Princeton University Press books are printed on acid-free paper and meet the guidelines for permanence and durability of the Committee on Production Guidelines for Book Longevity of the Council on Library Resources

First Princeton Paperback printing, in the Mythos series, 1997

http://pup.princeton.edu

Printed in the United States of America

$\begin{array}{llllllll}3 & 5 & 7 & 9 & 10 & 8 & 6 & 4\end{array}$ 